\title{
$4 \mathrm{~m}$

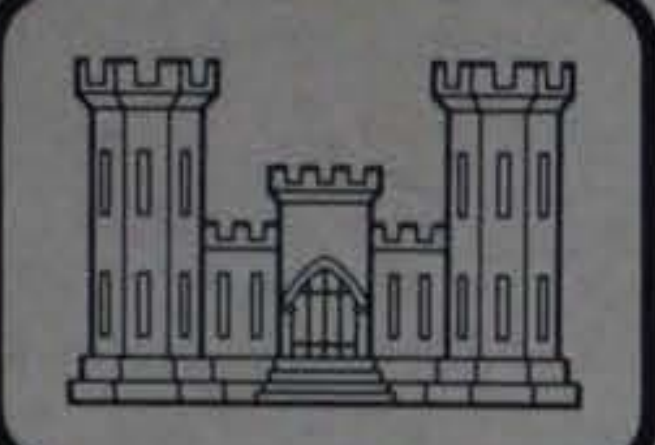

MISCELLANEOUS PAPER HL-79-1

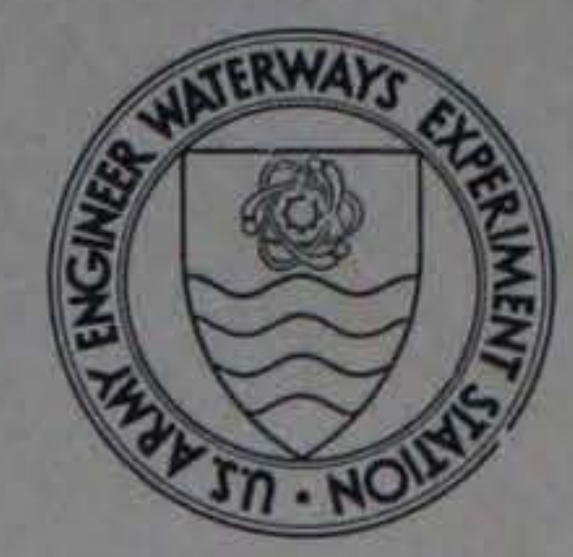

\section{LEVEE WAVE WASH PROTECTION BY TREES}

Hydraulic Model Investigation

by

Dennis G. Markle

Hydraulics Laboratory

U. S. Army Engineer Waterways Experiment Station

P. O. Box 631, Vicksburg, Miss. 39180

January 1979

Final Report

Approved For Public Release; Distribution Unlimited

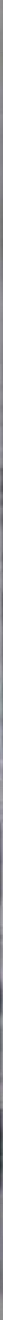

Prepared for U. S. Army Engineer District, Vicksburg

P. O. Box 80, Vicksburg, Miss. 39180 
Unclassified

SECURITY CLASSIFICATION OF THIS PAGE (Whon Date Enterod)

\begin{tabular}{|c|c|}
\hline REPORT DOCUMENTATION PAGE & $\begin{array}{l}\text { READ INSTRUCTIONS } \\
\text { BEFORE COMPLETING FORM }\end{array}$ \\
\hline $\begin{array}{l}\text { 1. REPORT NUMBER } \\
\text { Miscellaneous Paper HI-79-1 }\end{array}$ & 3. RECIPIENT'S CATALOG NUMBER \\
\hline \multirow{2}{*}{$\begin{array}{l}\text { 4. TITLE (and Subtitio) } \\
\text { LFVEE WAVE WASH PROTECTION BY TREES; } \\
\text { Hydraulic Model Investigation }\end{array}$} & $\begin{array}{l}\text { 5. TYPE OF REPORT \& PERIOD COVERED } \\
\text { Final report }\end{array}$ \\
\hline & 6. PERFORMING ORG. REPORT NUMBER \\
\hline $\begin{array}{l}\text { 7. AuthoR(0) } \\
\text { Dennis G. Markle }\end{array}$ & 8. CONTRACT OR GRANT NUMBER(a) \\
\hline $\begin{array}{l}\text { 9. PERFORMING ORGANIZATION NAME AND ADDRESS } \\
\text { U. S. Army Engineer Waterways Experiment Station } \\
\text { Hydraulics Laboratory } \\
\text { P. 0. Box } 631 \text {, Vicksburg, Miss. } 39180\end{array}$ & $\begin{array}{l}\text { 10. PROGRAM ELEMENT, PROJECT, TASK } \\
\text { AREA \& WORK UNIT'NUMBERS } \\
\text { Intra-Army Order No. } 3239\end{array}$ \\
\hline \multirow{2}{*}{$\begin{array}{l}\text { 11. CONTROLLING OFFICE NAME AND ADDRESS } \\
\text { U. S. Army Engineer District, Vicksburg } \\
\text { P. O. Box } 60 \\
\text { Vicksburg, Miss. } 39180\end{array}$} & $\begin{array}{l}\text { 12. REPORT DATE } \\
\text { January } 1979\end{array}$ \\
\hline & $\begin{array}{l}\text { 13. NUMBER OF PAGES } \\
21\end{array}$ \\
\hline \multirow[t]{2}{*}{ 14. MONITORING AGENCY NAME \& ADORESS(If difforent from Controlling Office) } & $\begin{array}{l}\text { 15. SECURITY CLASS. (of this roport) } \\
\text { Unclassified }\end{array}$ \\
\hline & $\begin{array}{l}\text { 15a. DECLASSIFICATION/DOWNGRADING } \\
\text { SCHEDULE }\end{array}$ \\
\hline
\end{tabular}

Approved for public release; distribution unlimited.

17. DISTRIBUTION STATEMENT (of the abstract ontered in Block 20, if difforent from Report)

18. SUPPLEMENTARY NOTES

19. KEY WORDS (Continue on reverse side If necessary and Identify by block number)

Branches Trees

Hydraulic models Wave wash

Levees Wave propagation

Stems (Botany)

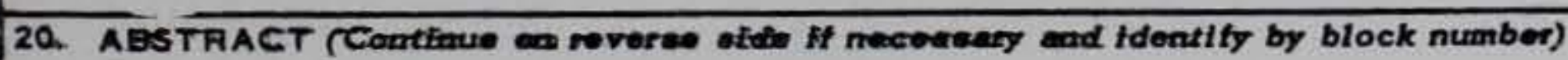

A hydraulic model investigation was conducted at a geometrically undistorted scale of $1: 5$, model to prototype. The purpose of the study was to test the use of tree stands as a possible method for protecting levee embankments from wave wash caused by wind- and boat-generated waves. Incident wave heights ranging from 1.0 to $3.0 \mathrm{ft}$ and wave periods of $2.0,2.5$, and $3.0 \mathrm{sec}$ were tested on a total of 12 different test plans. The 12 plans covered a

(Continued) 


\section{ABSTRACT (Continued).}

range of depths of tree stands using exclusively 4-in.- and 12-in.-diameter tree stems both with and without defoliated branch systems. The test results showed that for tree stems without branches the wave attenuation did not exceed a maximum of about 15 percent and on the average did not exceed about 9 percent. Tree stems with branch systems showed a maximum wave attenuation of about 45 percent, but the average wave attenuation did not exceed 15 percent. 


\section{PREFACE}

The model investigation reported herein was authorized by the $\mathrm{U}$. $\mathrm{S}$. Army Engineer District, Vicksburg (VED) Intra-Army Order No. 3239, dated 27 July 1976.

Model tests were conducted at the U. S. Army Engineer Waterways Experiment Station (WES) during the period September 1976 to February 1977 under the general direction of Mr. H. B. Simmons, Chief of the Hydraulics Laboratory; Dr. R. W. Whalin, Chief of the Wave Dynamics Division; and Mr. D. D. Davidson, Chief of the Wave Research Branch (WRB). Tests were conducted by Mr. D. G. Markle, Hydraulic Research Engineer, WRB, with assistance from Mr. C. Lewis, engineering technician, WRB. This report was prepared by Mr. Markle.

Liaison was maintained during the course of this investigation by conferences, telephone calls, and progress reports.

Commander and Director of WES during the conduct of the study and the preparation and publication of this report was COL John L. Cannon, CE. Technical Director was Mr. F. R. Brown. 
PREFACE

CONVERSION FACTORS, U. S. CUSTOMARY TO METRIC (SI)

UNITS OF MEASUREMENT

PART I: INTRODUCTION ..................... . . 4

The Prototype .................... . . . . 4

Purpose of Model Study . . . . . . . . . . . . . . 4

PART II: THE MODEL . . . . . . . . . . . . . . . . 6

Selection of Test Scales . . . . . . . . . . . . 6

Design of Model ... . . . . . . . . . . . . . . 6

Test Facilities and Equipment . . . . . . . . . . . 7

PART III: TESTS AND RESULTS . . . . . . . . . . . . . . . 9

Test Conditions . . . . . . . . . . . . . . . 9

Test Results . . . . . . . . . . . . . . . . . 9 9

PART IV: CONCLUSIONS AND RECOMMENDATIONS . . . . . . . . . . . 11

Conclusions . . . . . . . . . . . . . . . . . . 11

Recommendations ................... . . . 11

TABLE 1

PHOTOS $1-9$

PLATES 1 and 2 
CONVERSION FACTORS, U. S. CUSTOMARY TO METRIC (SI)

UNITS OF MEASUREMENT

U. S. customary units of measurement used in this report can be converted to metric (SI) units as follows:

Multiply

inches

feet

degrees (angle)

$\frac{\text { By }}{25.4}$
0.3048
0.01745329

To Obtain millimetres metres radians 


\section{LEVEE WAVE WASH PROTECTION BY TREES}

\section{Hydraulic Model Investigation}

\section{PART I: INTRODUCTION}

\section{The Prototype}

1. This investigation was not designated as a study for a specific problem occurring in one area, but as a general investigation of the use of tree stands to help protect levee embankments along inland waterways from wave wash caused by wind- and boatgenerated waves. The use of this native vegetation to attenuate wave attack on the levees during high river stages would produce benefits that are twofold. The obvious benefit would be the reduction in maintenance costs to repair the levees damaged by wave attack. The other benefit would be the low initial and long-term maintenance costs related to the use of naturally occurring vegetation rather than conventional protection methods. In addition, the trees could then be controlled and harvested, and new stands planted, thereby producing a return on the investment. Cottonwood trees were selected for test simulation because of their fast growth rate and suitability to flood zone areas. Since there are an infinite number of tree patterns and spacings that could be employed in the prototype, the tests described herein were limited to one pattern and spacing, which was considered an optimum planting arrangement.

\section{Purpose of Model Study}

2. The purpose of the hydraulic model study was to measure the wave attenuation produced by cottonwood trees when the water level passed through the tree stems and when the water level passed through the branch system of the trees. These data could then be 


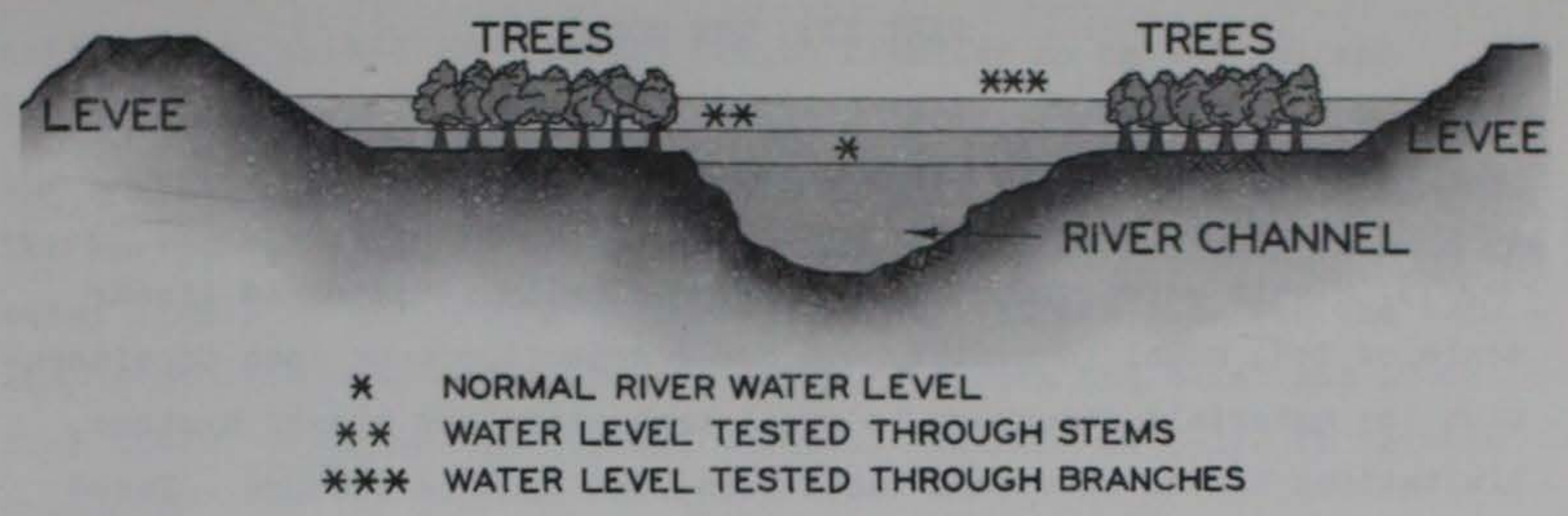

Figure 1. Levee wave wash protection by trees

be used to approximate the amount of wave protection during various river stages that could be expected from a stand of trees planted between a river channel and levee embankment (Figure 1 ). 


\section{Selection of Test Scales}

3. Tests were conducted at a geometrically undistorted linear scale of 1:5, model to prototype. Scale selection took into consideration the materials necessary to model tree stems and branch systems, limitations of the wave tank facilities, and scaling factors. Based on the above considerations, Froude's model law* and a linear scale of 1:5 were used to derive the following model-to-prototype relationships:

Characteristics Dimensions Model-Prototype Scale Relations

$\begin{array}{lll}\text { Length } & \mathrm{L} & \mathrm{L}_{r}=1: 5 \\ \text { Area } & \mathrm{L}^{2} & \mathrm{~A}_{r}=L_{r}^{2}=1: 25 \\ \text { Volume } & \mathrm{L}^{3} & \mathrm{~V}_{r}=L_{r}^{3}=1: 125 \\ \text { Time } & \mathrm{T} & \mathrm{T}_{r}=L_{r}^{1 / 2}=1: 2.24\end{array}$

Design of Model

4. Both 4-in. -* and 12-in.-diameter tree stems were modeled using 3-ft lengths of plastic-standard number 40-PVC pipe, Photos 1 and 2, respectively. A field survey of cottonwood trees, combined with the analysis of other available data ${ }^{\dagger},{ }^{\dagger}+$ on trees very similar to the

* J. C. Stevens et al., "Hydraulic Models," Manual of Engineering Practice No. 25, 1942, American Society of Civil Engineers, New York, N. Y.

** A table for converting U. S. customary units of measurement to metric (SI) units is presented on page 3.

$+H$. W. West and H. H. Allen, "A Technique for Quantifying Forest Stands for Management Evaluations," Technical Report M-71-9, Dec 1971, U. S. Army Engineer Waterways Experiment Station, CE, Vicksburg, Miss.

t+ U. S. Army Engineer Waterways Experiment Station, CE, "Plant Data Retrieval System," Computer Program (704-G9RO-238, Fortran IV), Mobility and Environmental Systems Laboratory, Vicksburg, Miss. 
cottonwoods, showed the average branch diameter to be $5 / 8$ in. and 1-1/4 in. for 4-in.- and 12-in.-diameter trees, respectively. The angle the branches made with the stems of the trees ranged from 30 to $60 \mathrm{deg}$. The horizontal distance measured from the center of the tree stem to the outer limits of the branch systems averaged $4 \mathrm{ft}$ and $6 \mathrm{ft}$ for the 4-in.and 12-in.-diameter stems, respectively. On both the 4-in. and 12-in. tree stems, there was an average vertical distance of $2-1 / 2 \mathrm{ft}$ between branch systems.

5. Based on these data, the PVC pipe was drilled and hardwood dowel pins of appropriate length and diameter were inserted to produce the two styles of branch systems that were tested (Photos 3 and 4 ). Due to the high degree of variations and concentrations of tree foliage, the plans tested did not include modeling of the tree foliage.

6. When either the 4-in. or 12-in. tree stems were tested with or without branches, they were anchored to the test flume floor in the pattern shown in Figure 2. The pattern was continued for the three depths of tree stems (i.e., horizontal distance from the front row to the last row of trees) that were tested: 140,300, and $460 \mathrm{ft}$.

\section{Test Facilities and Equipment}

7. A portion of the L-shaped wave flume (Figure 3) was used for all tests. The wave flume was equipped with a flap-type wave generator capable of producing monochromatic waves of various heights and periods. The model trees were tested in an area $106 \mathrm{ft}$ long and $15 \mathrm{ft}$ wide (Figure 3), and approximately $50 \mathrm{ft}$ from the wave generator. Changes in water-surface elevation (wave heights) as a function of time were measured as they entered and exited each test depth of tree stems by electrical parallel-wire resistance type gages. The output of these gages was fed through an electrical amplifier-converter and then recorded on chart paper by an electrically operated oscillograph. 


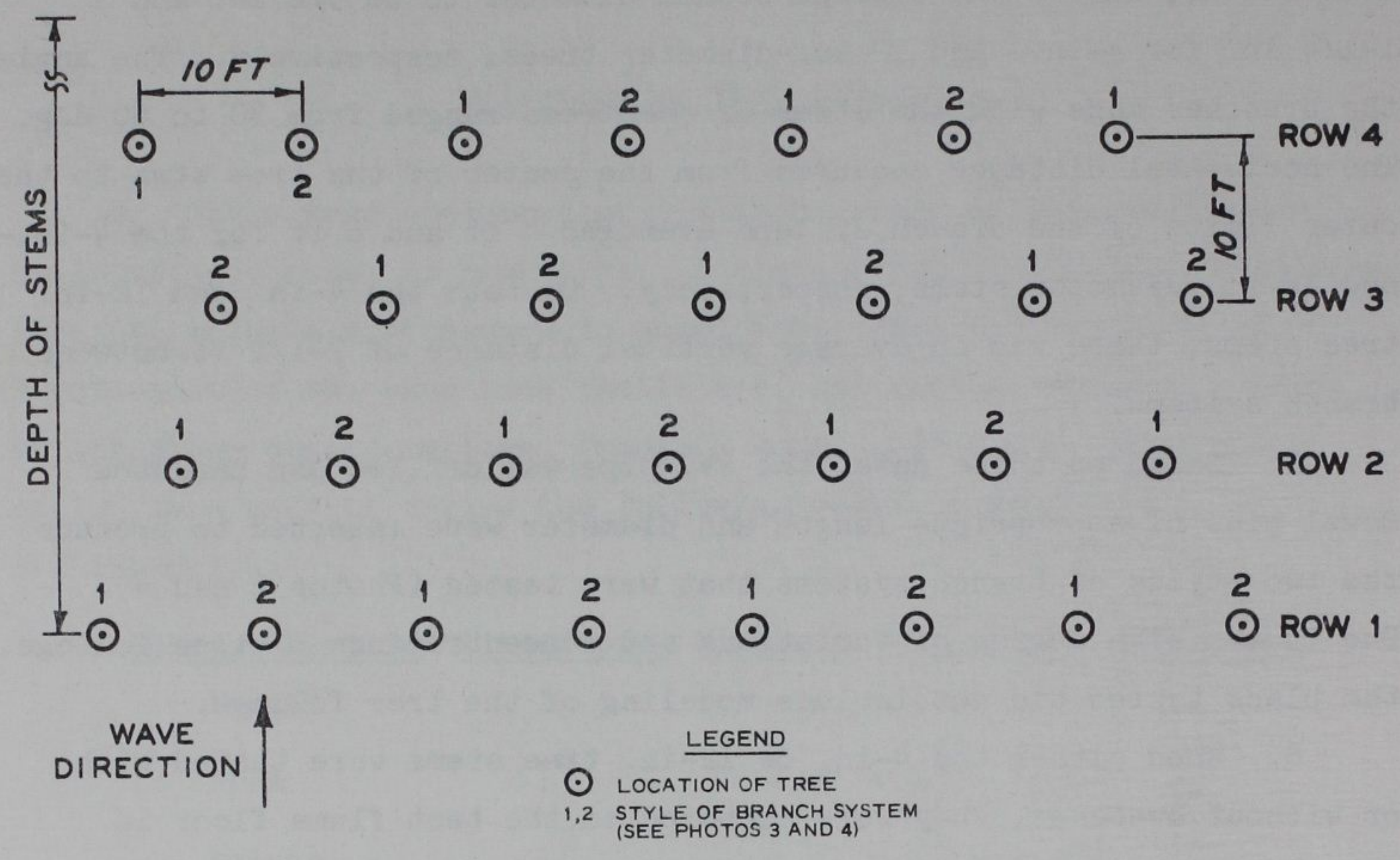

Figure 2. Tree pattern and spacing. (Note: pattern repeats every four rows.)
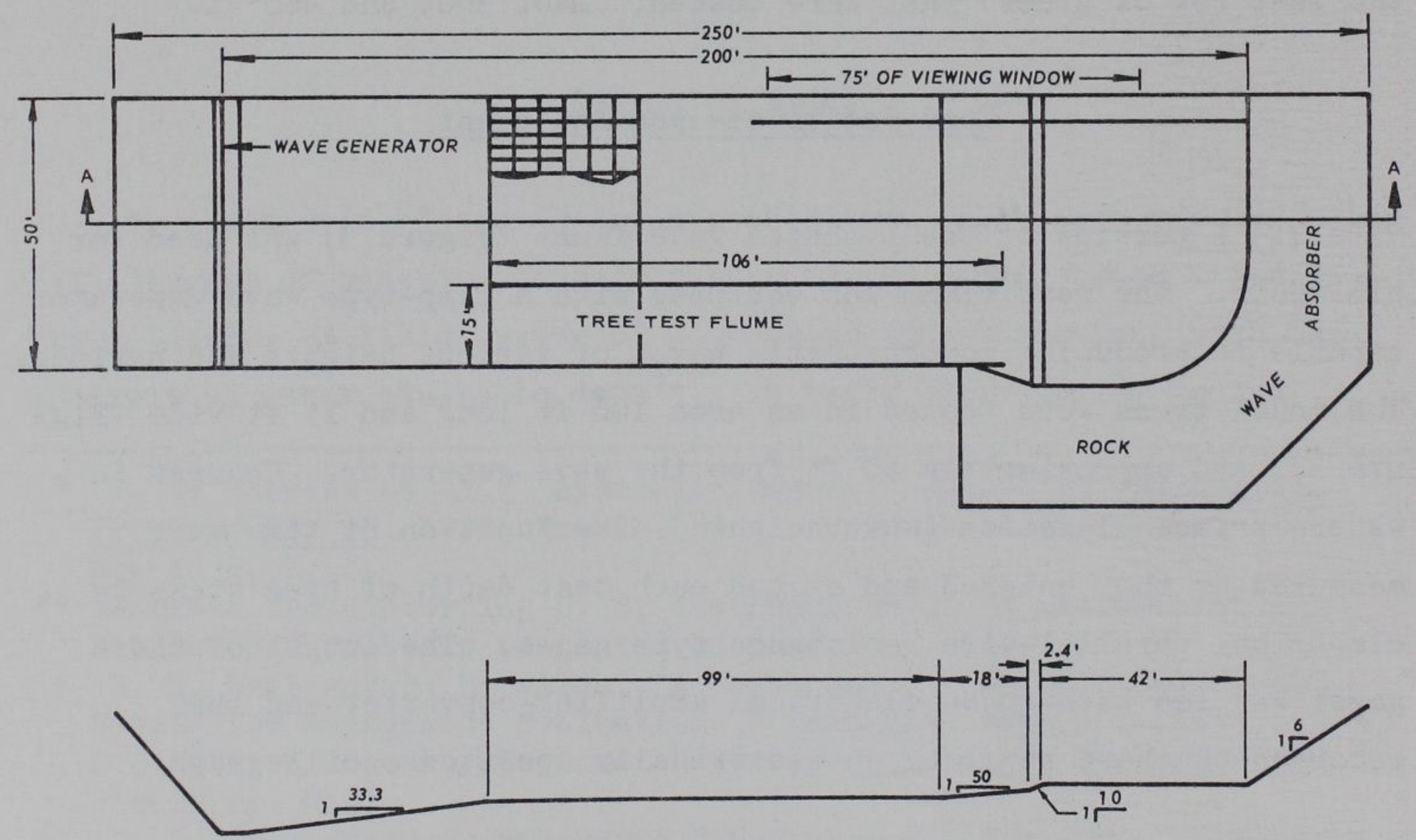

SECTION A-A

Figure 3. L-shaped wave flume 


\section{Test Conditions}

8. A total of 12 plans were tested as tabulated below:

\begin{tabular}{|c|c|c|c|c|}
\hline $\begin{array}{c}\text { Plan } \\
\text { Number } \\
\end{array}$ & $\begin{array}{c}\begin{array}{c}\text { Stem } \\
\text { Diameter } \\
\text { in. }\end{array} \\
\end{array}$ & $\begin{array}{c}\text { Depth of } \\
\text { Trees } \\
\mathrm{ft} \\
\end{array}$ & $\begin{array}{l}\text { With or } \\
\text { Without } \\
\text { Branches }\end{array}$ & $\begin{array}{c}\text { Branch } \\
\text { Diameter } \\
\text { in. } \\
\end{array}$ \\
\hline 1 & 4 & 140 & Without & -- \\
\hline 2 & 4 & 300 & Without & -- \\
\hline 3 & 4 & 460 & Without & -- \\
\hline 4 & 4 & 140 & With & $5 / 8$ \\
\hline 5 & 4 & 300 & With & $5 / 8$ \\
\hline 6 & 4 & 460 & With & $5 / 8$ \\
\hline 7 & 12 & 140 & Without & -- \\
\hline 8 & 12 & 300 & Without & -- \\
\hline 9 & 12 & 460 & Without & -- \\
\hline 10 & 12 & 140 & With & $1-1 / 4$ \\
\hline 11 & 12 & 300 & With & $1-1 / 4$ \\
\hline 12 & 12 & 460 & With & $1-1 / 4$ \\
\hline
\end{tabular}

All tests used a placement pattern identical to Figure 2 with an incident wave angle of $90 \mathrm{deg}$ to the rows of trees. Incident wave heights ranging from approximately 1.0 to $3.0 \mathrm{ft}$ for wave periods of $2.0,2.5$, and $3.0 \mathrm{sec}$ were tested for each of the 12 plans. A model water depth of $2 \mathrm{ft}$ was used for all tests. For the wave heights and wave periods tested, this was sufficient depth to ensure that bottom friction would not play a significant part in the wave attenuation. However, to be sure that any dissipation due to flume effects (wall friction, bottom connections, etc.) was not included in the test results, wave attenuation without the trees in the flume was measured for the three tested depths of tree stems and subtracted from the total attenuation recorded during the tree tests. In this way, the final data only show the wave reduction due to the various depths of tree stems, with or without branches.

Test Results

9. Numerical results of all test conditions run on Plans $1-12$ are 
listed in Table 1 and plotted on Plates 1 and 2. Photo 5 shows Plan 4 without water in the flume.* The two gages located in the background measured incident wave height, and the two gages in the foreground measured transmitted wave height. Plan 10, with and without water, is shown in Photos 6 and 7, respectively. The maximum depth of tree stems with branches (Plan 12) is shown with and without water in Photos 8 and 9, respectively.

10. Plans $1-6$ showed very minimal wave attenuation for all three wave periods tested, but a general trend of increasing wave-height dissipation can be seen for decreasing wave period and increasing depth of tree stems. Somewhat larger wave attenuations, with the same general trend as shown by Plans 1-6, can be seen for Plans 7-12; however, the only significant decrease in wave height is shown by Plans 11 and 12 for the 2-sec wave period only.

11. In general, for the given wave conditions and designated tree pattern and spacing, wave attenuation by tree stems is not expected to exceed a maximum of about 15 percent and on the average will not exceed about 9 percent. For the same test conditions, wave attenuation through the tree branches is not expected to exceed a maximum of 45 percent and on the average will be closer to 15 percent.

12. Based on the limited tests conducted and since foliage was not represented, it is believed that results of these tests represent the lower limit of wave attenuation. Other types of trees or shrubs that have more concentrated branches may provide better wave attenuation. Also, if a feasible means were found to model the foliage, and then verify that it was modeled correctly, a much higher wave attenuation might result. It should be kept in mind, however, that unless the trees or shrubs are evergreen, the wave attenuation produced by the foliage will be lost during the late fall and winter months. The foliage could also be stripped off by wave and current action during the spring and summer months.

* Photos 5-9 of the model were taken looking toward the wave generator. 


\section{Conclusions}

13. Based on the tests conducted herein, it is concluded that wave attenuation by tree stems alone, approximately 9 percent, is not very effective and on the average would afford only minimum protection. Wave attenuation through the branch system without foliage increases to about 15 percent on the average; but again, this can only be considered minimum protection. For either of the tree schemes tested, with or without branches, and considerable depth of tree stems (Plates I and 2) would be required to attenuate the proposed wave action effectively.

\section{$\underline{\text { Recommendations }}$}

14. It is realized that the model representation of the tree schemes reported herein was limited to a first approximation and does not represent all the detail parameters involved. For instance, foliage and small underbrush were purposely left out due to their indeterminate nature, which could only be verified by prototype attenuation data, and due to their supposable secondary effects on wave attenuation during the winter season. If prototype data existed to verify these parameters, the model would then become a more useful tool in the evaluation process. Although the tests reported herein were a valuable first step in understanding the tree attenuation process, it is recommended that further insight be gained by conducting additional tests with foliage that are verified by at least one set of prototype attenuation data, or that a full-scale prototype study be conducted in which sufficient wave attenuation measurements are made to quantify the tree protection concept under varying conditions. 
Table 1

Wave Transmission Coefficients, Plans 1-12

\begin{tabular}{|c|c|c|c|c|c|c|}
\hline $\begin{array}{l}\text { Plan } \\
\text { Number }\end{array}$ & $\begin{array}{c}\text { Stem } \\
\text { Di ameter } \\
\text { in. } \\
\end{array}$ & $\begin{array}{c}\text { Depth of } \\
\text { Trees } \\
\text { ft }\end{array}$ & $\begin{array}{c}\text { Branch } \\
\text { Diameter } \\
\text { in. } \\
\end{array}$ & $\begin{array}{c}\text { Wave } \\
\text { Period } \\
\text { sec } \\
\end{array}$ & $\begin{array}{c}\text { Range of } \\
\text { Incident } \\
\text { Wave Heights } \\
\mathrm{ft} \\
\end{array}$ & $\begin{array}{l}\text { Transmission } \\
\text { Coefficient* }\end{array}$ \\
\hline 1 & 4 & 140 & ** & $\begin{array}{l}2.0 \\
2.5 \\
3.0\end{array}$ & $\begin{array}{l}1.1-2.5 \\
1.1-3.4 \\
1.0-3.2\end{array}$ & $\begin{array}{l}0.92 \\
0.94 \\
0.95\end{array}$ \\
\hline 2 & 4 & 300 & ** & $\begin{array}{l}2.0 \\
2.5 \\
3.0\end{array}$ & $\begin{array}{l}1.1-2.4 \\
0.9-3.0 \\
0.7-2.8\end{array}$ & $\begin{array}{l}0.95 \\
0.98 \\
0.96\end{array}$ \\
\hline 3 & 4 & 460 & ** & $\begin{array}{l}2.0 \\
2.5 \\
3.0\end{array}$ & $\begin{array}{l}1.1-2.4 \\
1.0-3.1 \\
0.9-2.7\end{array}$ & $\begin{array}{l}0.87 \\
0.93 \\
0.95\end{array}$ \\
\hline 4 & 4 & 140 & $5 / 8$ & $\begin{array}{l}2.0 \\
2.5 \\
3.0\end{array}$ & $\begin{array}{l}1.2-2.3 \\
0.9-3.2 \\
0.8-2.7\end{array}$ & $\begin{array}{l}0.91 \\
0.93 \\
1.00\end{array}$ \\
\hline 5 & 4 & 300 & $5 / 8$ & $\begin{array}{l}2.0 \\
2.5 \\
3.0\end{array}$ & $\begin{array}{l}1.1-2.2 \\
0.9-2.9 \\
0.8-2.6\end{array}$ & $\begin{array}{l}0.88 \\
0.94 \\
0.96\end{array}$ \\
\hline 6 & 4 & 460 & $5 / 8$ & $\begin{array}{l}2.0 \\
2.5 \\
3.0\end{array}$ & $\begin{array}{l}1.1-2.3 \\
1.0-3.0 \\
0.9-2.5\end{array}$ & $\begin{array}{l}0.91 \\
0.92 \\
0.90\end{array}$ \\
\hline 7 & 12 & 140 & $* *$ & $\begin{array}{l}2.0 \\
2.5 \\
3.0\end{array}$ & $\begin{array}{l}1.2-2.7 \\
1.0-3.3 \\
1.0-3.0\end{array}$ & $\begin{array}{l}0.82 \\
0.95 \\
0.95\end{array}$ \\
\hline 8 & 12 & 300 & $* *$ & $\begin{array}{l}2.0 \\
2.5 \\
3.0\end{array}$ & $\begin{array}{l}1.1-2.4 \\
1.0-3.2 \\
0.9-3.1\end{array}$ & $\begin{array}{l}0.87 \\
0.97 \\
0.93\end{array}$ \\
\hline 9 & 12 & 460 & $* *$ & $\begin{array}{l}2.0 \\
2.5 \\
3.0\end{array}$ & $\begin{array}{l}1.1-2.9 \\
0.9-2.9 \\
0.9-2.7\end{array}$ & $\begin{array}{l}0.83 \\
0.92 \\
0.94\end{array}$ \\
\hline 10 & 12 & 140 & $1-1 / 4$ & $\begin{array}{l}2.0 \\
2.5 \\
3.0\end{array}$ & $\begin{array}{l}1.1-2.4 \\
0.9-3.0 \\
0.8-2.8\end{array}$ & $\begin{array}{l}0.76 \\
0.91 \\
0.89\end{array}$ \\
\hline 11 & 12 & 300 & $1-1 / 4$ & $\begin{array}{l}2.0 \\
2.5 \\
3.0\end{array}$ & $\begin{array}{l}1.1-2.3 \\
0.9-3.1 \\
0.8-3.0\end{array}$ & $\begin{array}{l}0.67 \\
0.87 \\
0.90\end{array}$ \\
\hline 12 & 12 & 460 & $1-1 / 4$ & $\begin{array}{l}2.0 \\
2.5 \\
3.0\end{array}$ & $\begin{array}{l}1.2-2.3 \\
0.9-3.2 \\
0.9-2.8\end{array}$ & $\begin{array}{l}0.54 \\
0.85 \\
0.83\end{array}$ \\
\hline
\end{tabular}

* Does not include wave attenuation due to flume wall and floor friction.

** Without branches. 


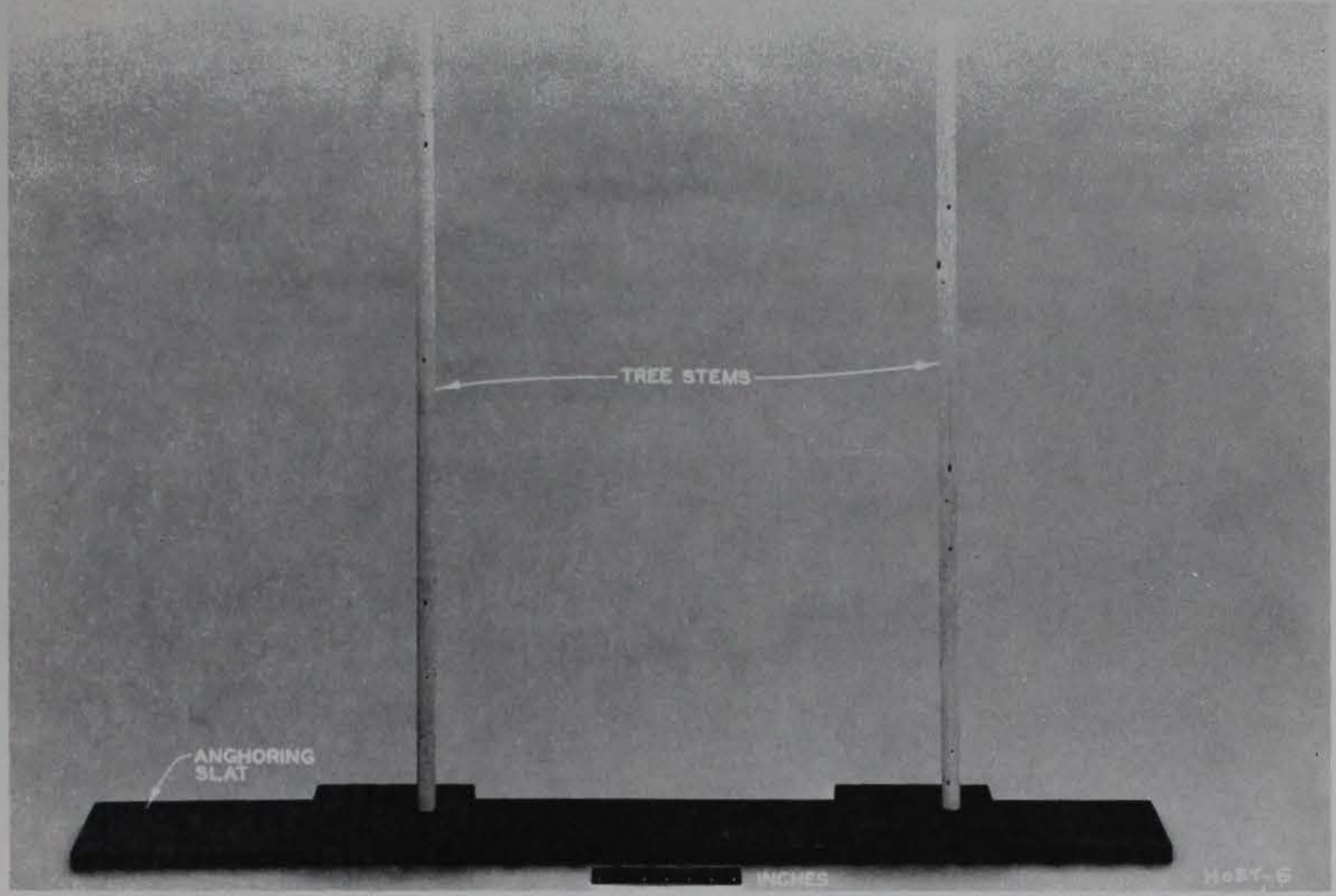

Photo 1. 4-in.-diameter stems without branches, used in Plans 1-3

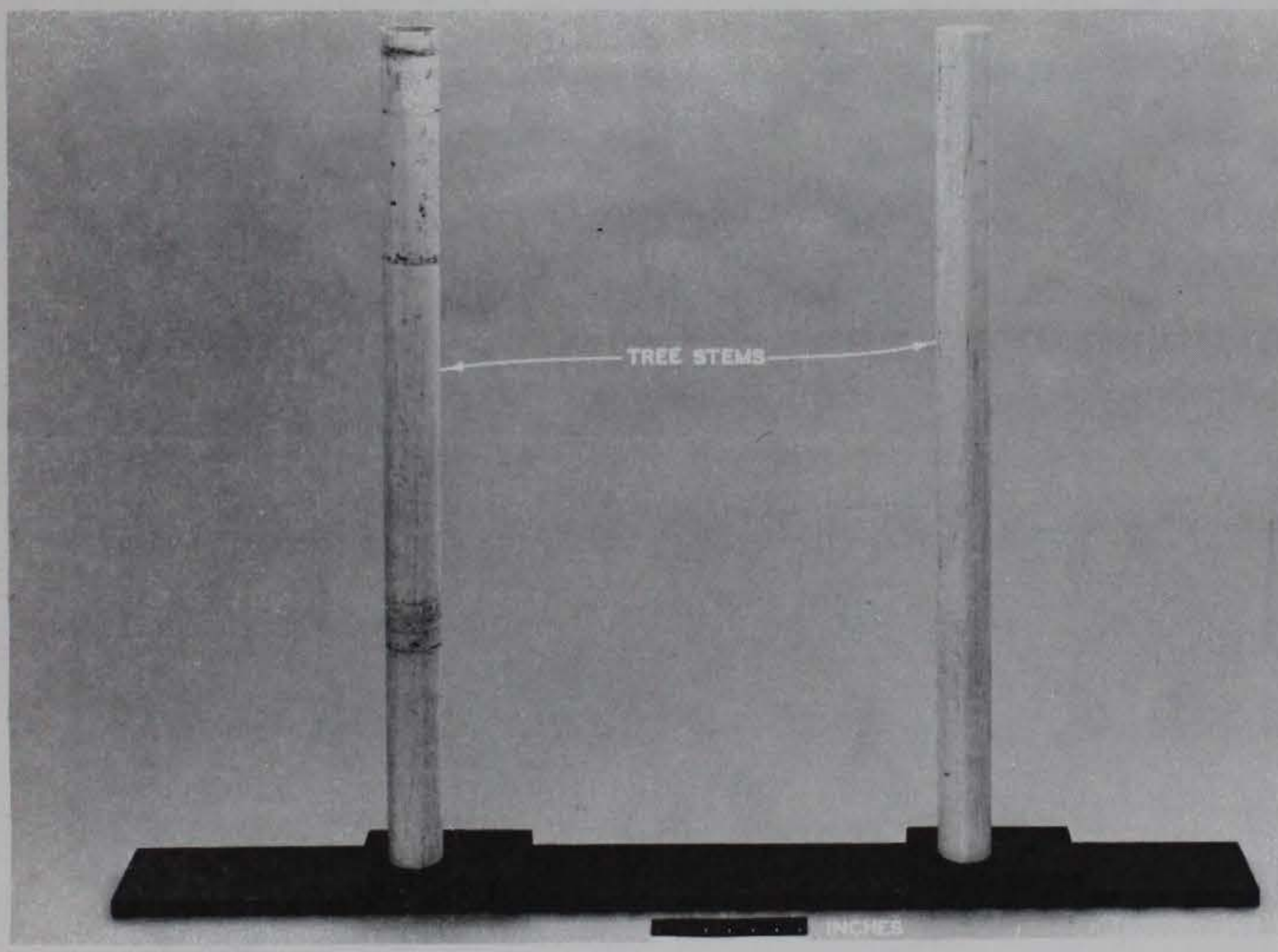

Photo 2. 12-in.-diameter stems without branches, used in Plans 5-7 


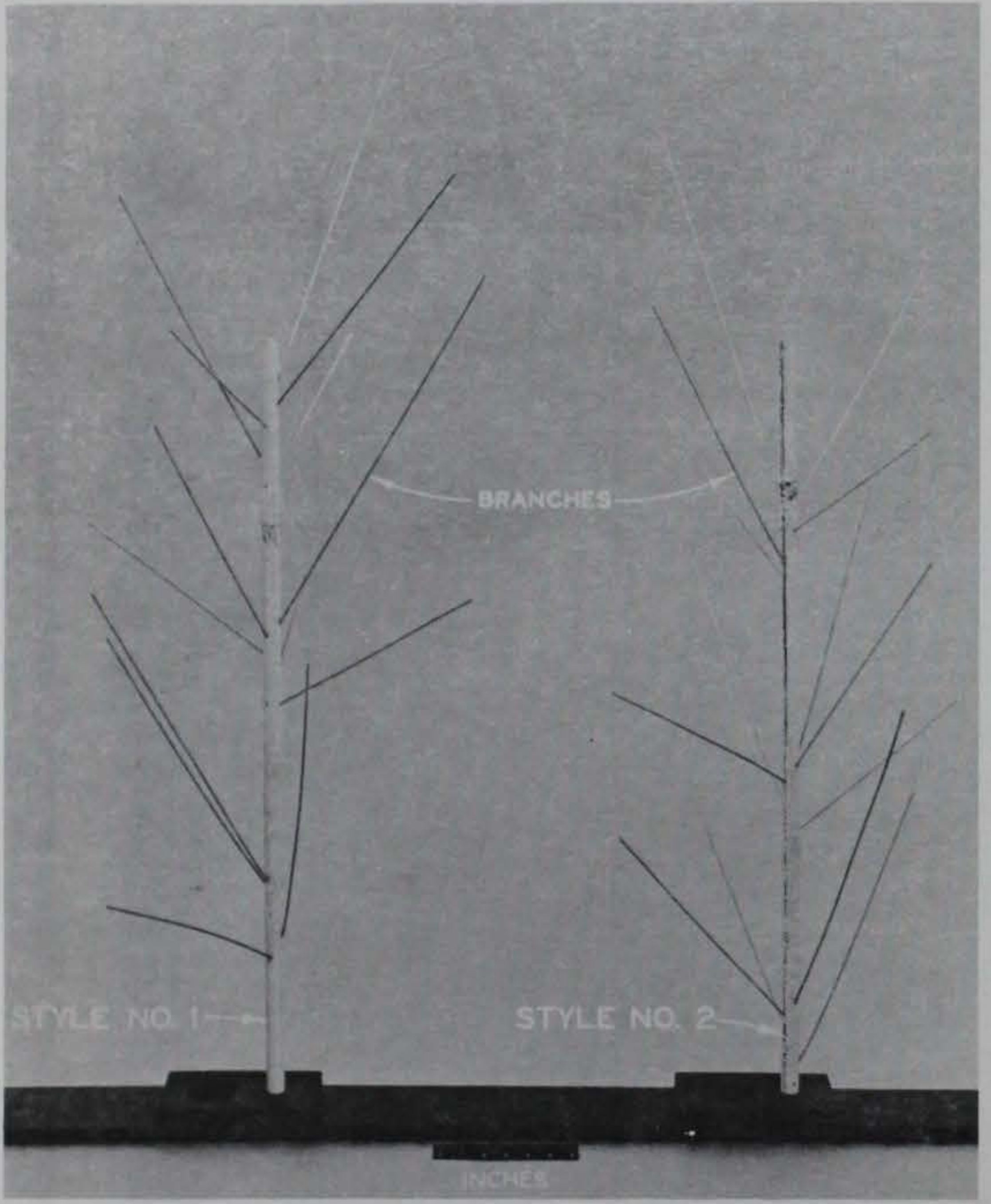

Photo 3. 4-in.-diameter stems with

5/8-in. branches. Styles 1 and 2 used in Plans 4-6

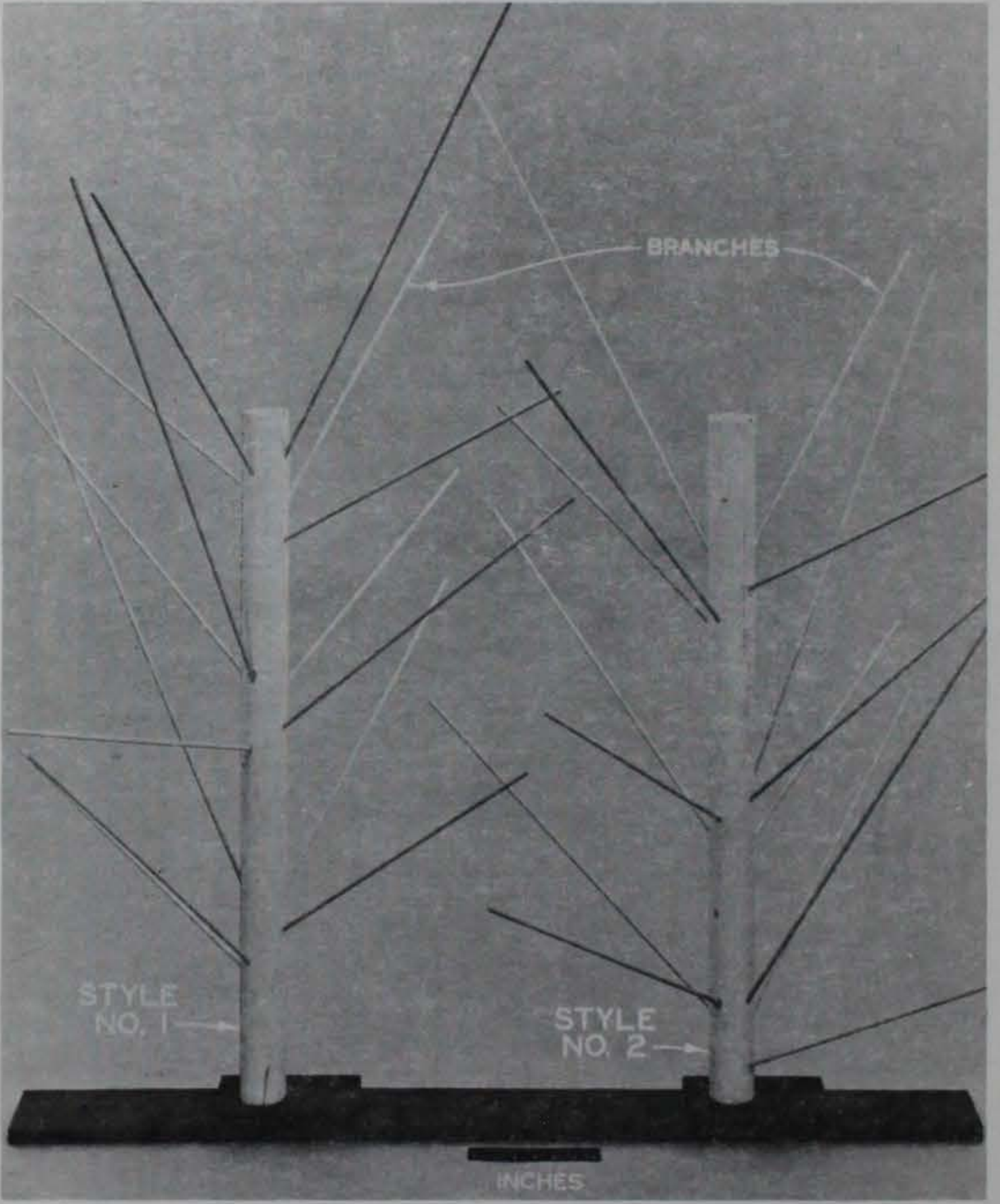

Photo 4. 12-in.-diameter stems with

1-1/4-in. branches. Styles 1 and 2 used in Plans 10-12 


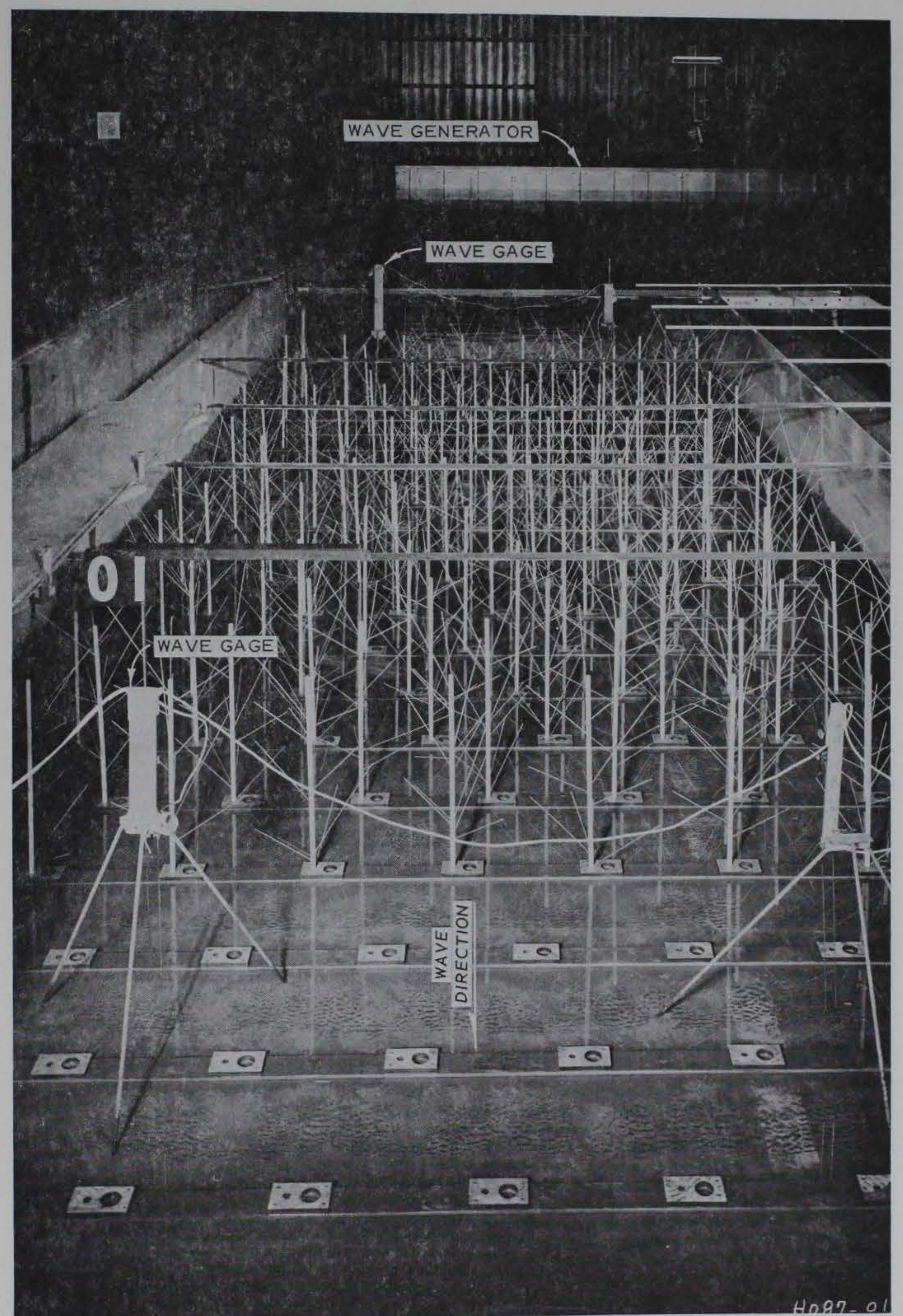

Photo 5. Plan 4, 4-in.-diameter stems with 5/8-in. branches without water in flume 




Photo 6. Plan 10, 12-in.-diameter stems with 1-1/4-in. branches with model water depth of $2.0 \mathrm{ft}$ 


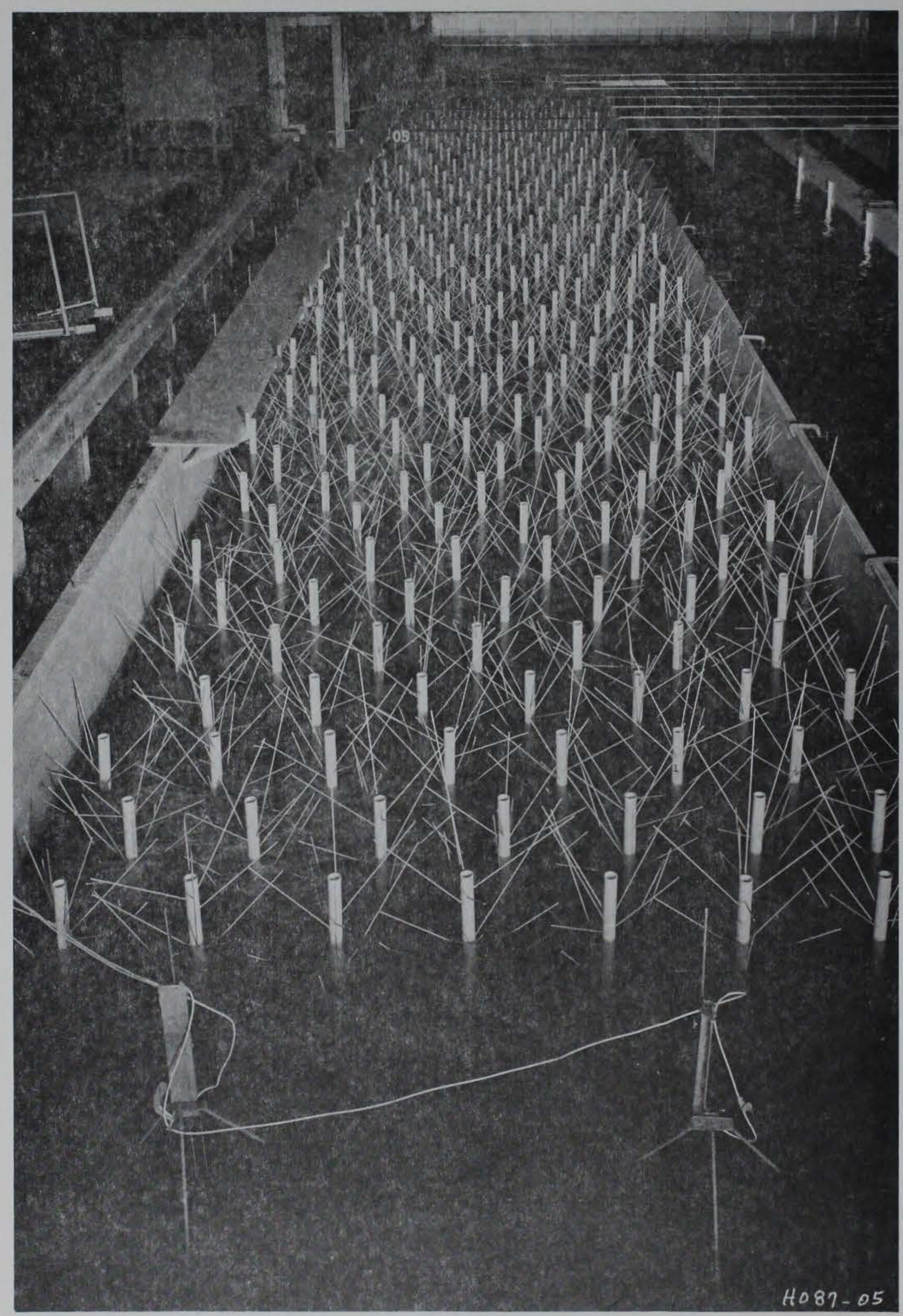

Photo 8. Plan 12, 12-in.-diameter stems with 1-1/4-in. branches with model water depth of $2.0 \mathrm{ft}$ 


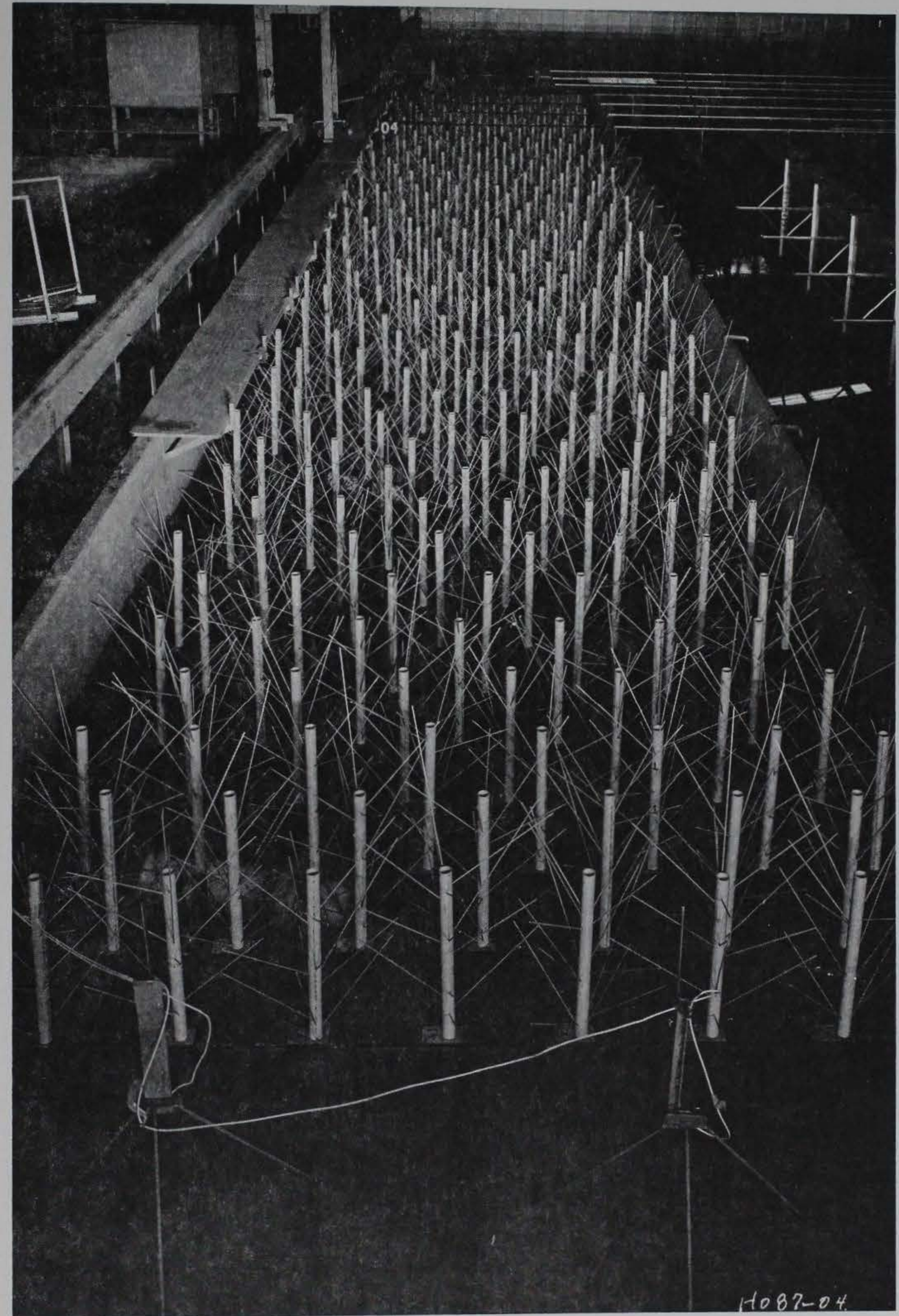

Photo 9. Plan 12, 12-in.-diameter stems with 1-1/4-in. branches without water in flume 


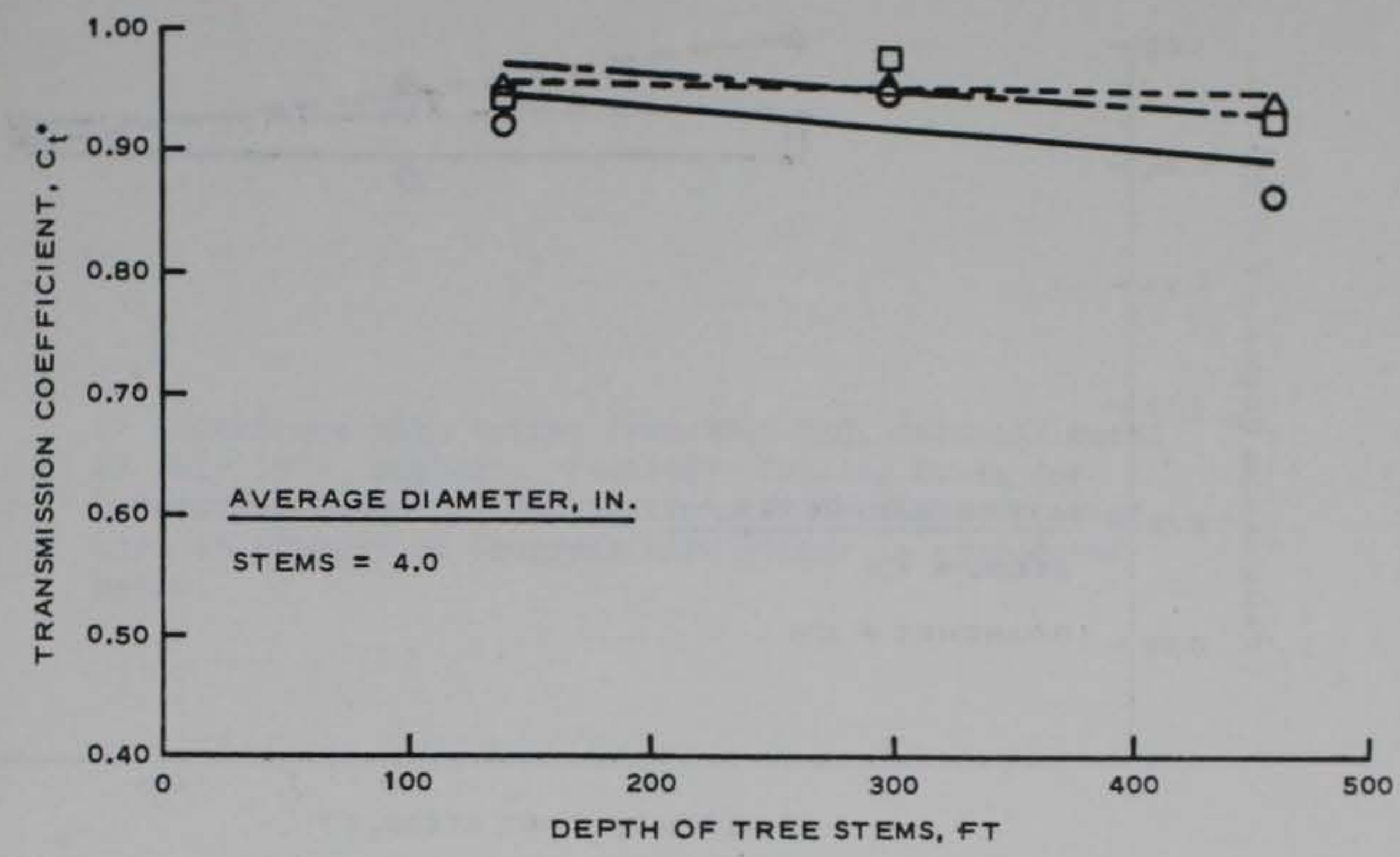

a. PLANS 1 - 3

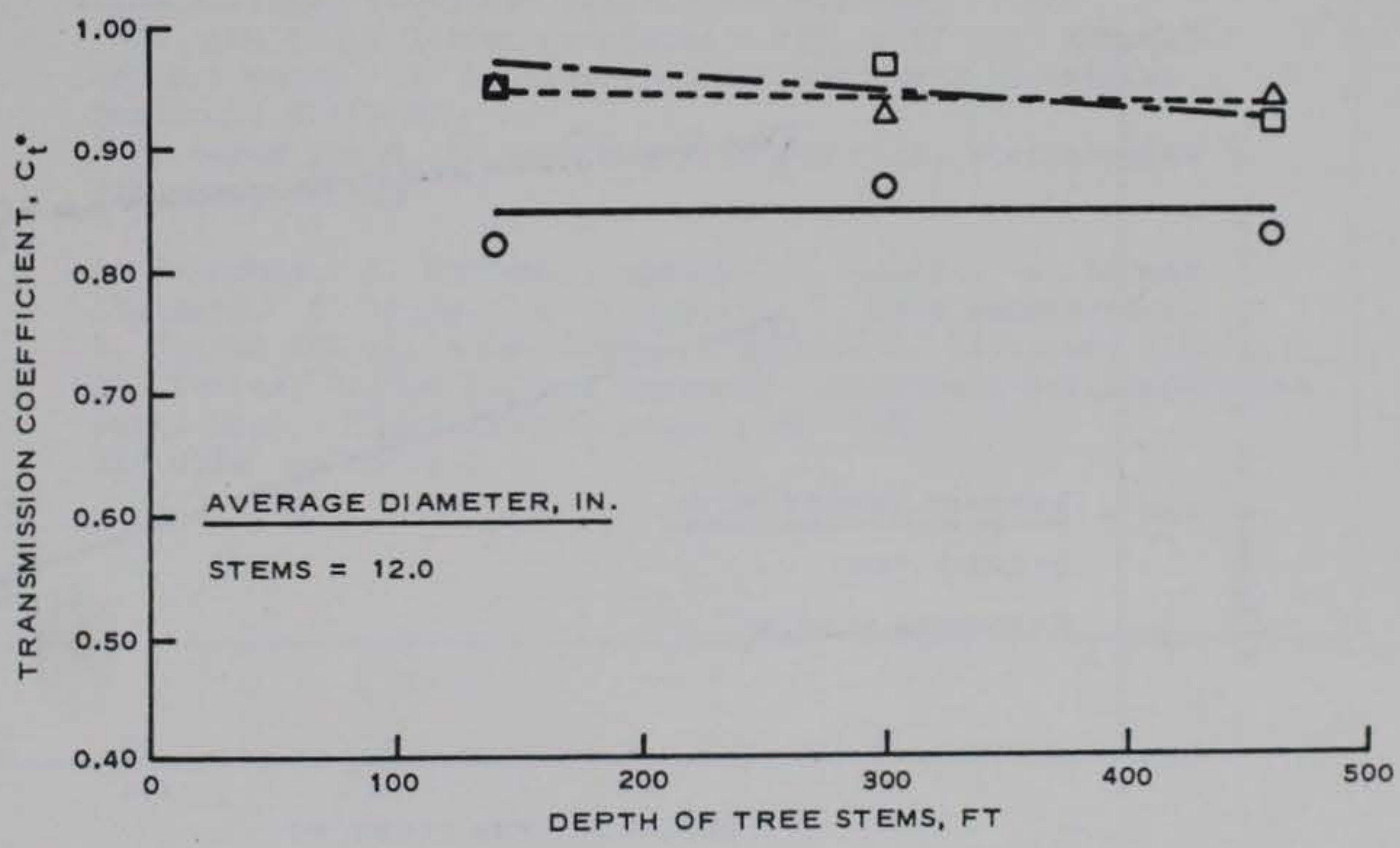

b. PLANS 7 - 9

- $c_{t}=$ TRANSMITTED/INCIDENT WAVE HEIGHT

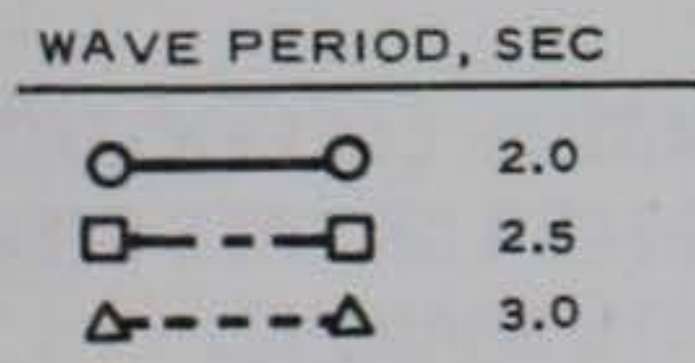
VERSUS DEPTH OF TREE STEMS WITHOUT BRANCHES 


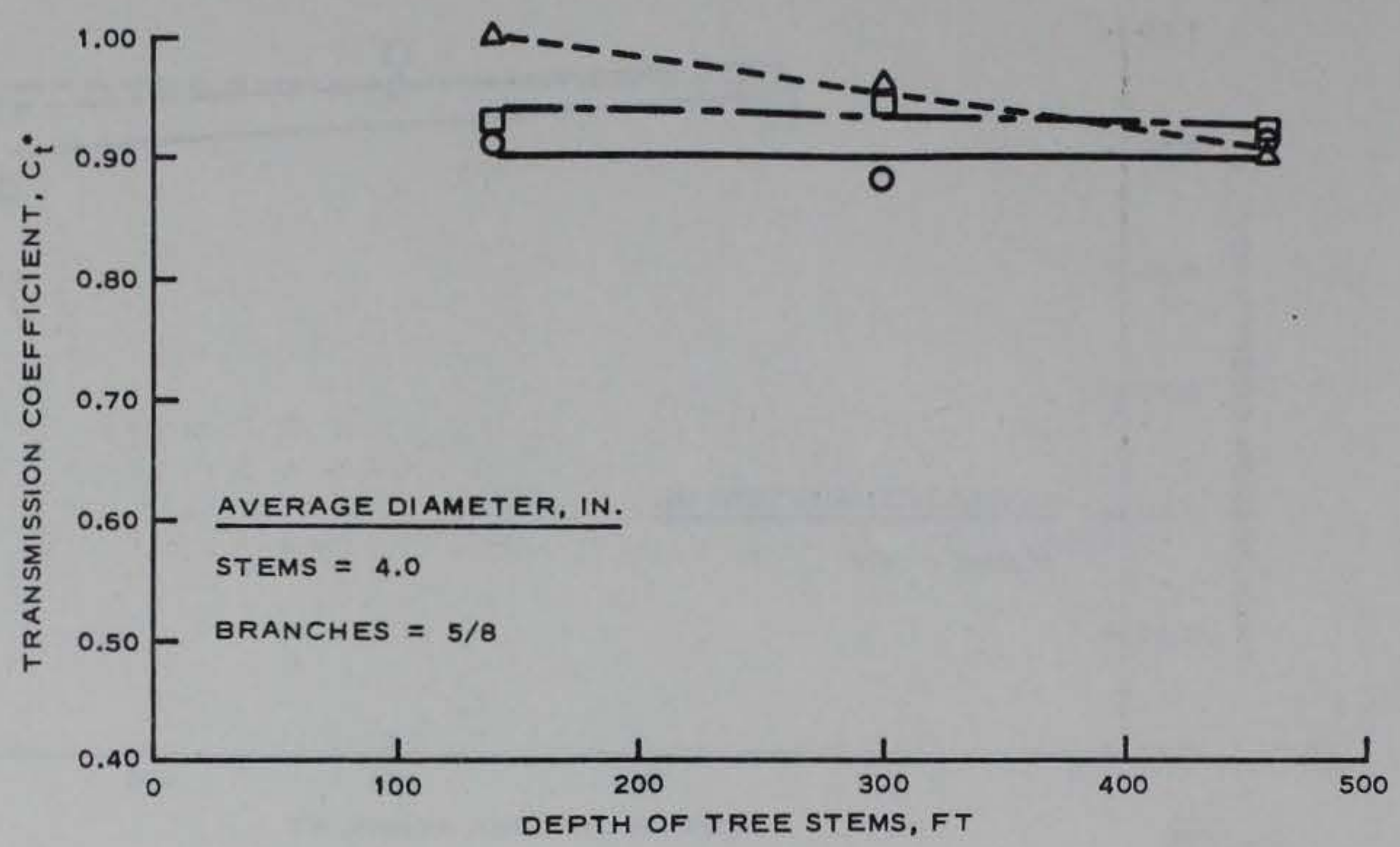

a. PLANS 4-6

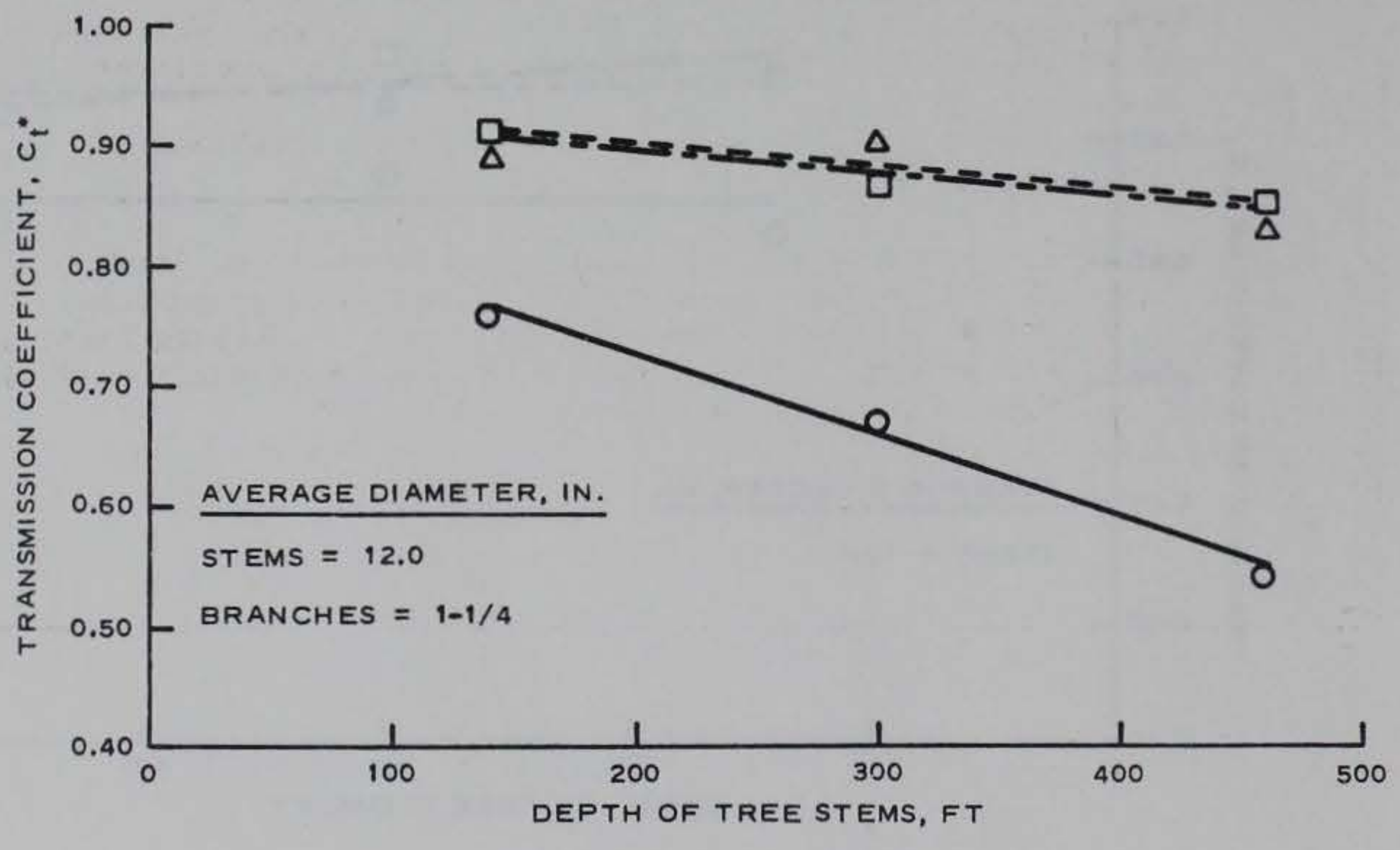

b. PLANS 10 - 12

- $c_{t}=$ TRANSMITTED/INCIDENT WAVE HEIGHT

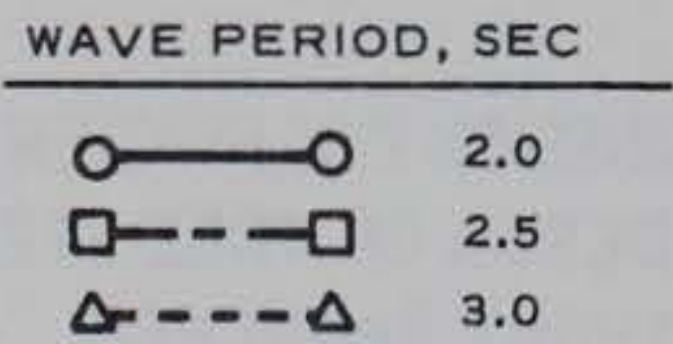

